\title{
Purification and Properties of Carp Muscle Cathepsin A
}

\author{
Haruhiko ToYoHARA*, Yasuo MAKINODAN*, and Shizunori IKEDA* \\ (Received December 17, 1981)
}

\begin{abstract}
To clarify the post-mortem proteolysis of fish muscle, carp muscle cathepsin $\mathrm{A}$ was purified and its properties were investigated. The purification was about 1,700 -fold, with a yield of $1.5 \%$. The purification procedures were as follows: acid treatment, heat treatment, ammonium sulfate fractionation, acetone fractionation, DEAE-Sephadex A-50 chromatography, preparative electrofocusing, and Sepharose $6 \mathrm{~B}$ gel filtration.

The enzyme hydrolyzed Z-Glu-Phe more preferably than Z-Glu-Tyr, with the optimum pH was 5.0. The $\mathrm{Km}$ values for Z-Glu-Phe and Z-Glu-Tyr were estimated to be $3.52 \mathrm{~mm}$ and 4.76 $\mathrm{mm}$, respectively. Z-Gly-Pro was not hydrolyzed by the enzyme. On the other hand, the enzyme did not act on any protein substrates used. The enzyme activity was completely inhibited by Dip-F, PMSF, iodoacetamide, and antipain, but activated by 2 -mercaptoethanol, NaI, and NaBr. Therefore, serine and cysteine residues may be involved for the activity. Pepstatin, EDTA, and $o$-phenanthroline had no effect on the activity. The molecular weight of the enzyme was estimated to be 36,000 by gel filtration and the isoelectric point to be 4.6 .

At pH 5.0, carp muscle homogenate autolyzed considerably at $37^{\circ} \mathrm{C}$ for 24 hours. But cathepsin A had no electorphoretically recognizable effect on the autolysis. Therefore, the enzyme doesn't seem to participate directly in post-mortem degradation of fish muscle.
\end{abstract}

Since cathepsin A (EC 3.4.16.1) was first found in bovine spleen, ${ }^{12}$ it has been shown to distribute widely in animal tissues. ${ }^{2}$ However, the homogeneous preparations were only obtained from bovine spleen, ${ }^{3,4)}$ rat liver ${ }^{6,8)}$ and pig kidney, ${ }^{7,8)}$ but not from muscle. MAKINODAN and IKEDA ${ }^{8)}$ clarified the existence of cathepsin $A$ in fish muscle and investigated the properties of the enzyme. ${ }^{10}$ But the enzyme preparation still contained contaminated proteins, and so it was desirable to get a homogeneous preparation to know the preciser properties of the enzyme.

In this study, we have purified cathepsin A from carp muscle as an electrophoretically homogeneous preparation and reinvestigated its properties. Whether the enzyme participates in the fish muscle autolysis is also discussed.

\section{Materials and Methods}

Materials

Carp Cyprinus carpio of appoximately $900 \mathrm{~g}$ were obtained alive from a commercial supplier.

DEAE-Sephadex A-50 and Sephrose 6B were purchased from Pharmacia Fine Chemicals, Uppsala, Sweden; Ultrodex and Ampholine were obtained from LKB-Productor, Stockholm,
Sweden; hemoglobin was a product of Difco Laboratories, Detroit, U.S.A.; bovine serum albumin, ovalbumin, chymotrypsinogen $\mathrm{A}$, myoglobin, cytochrome $\mathrm{c}$, insulin and glucagon were obtained from Sigma Chemical Co., St. Louis, U.S.A.; synthetic substrates were purchased from the Protein Research Foundation, Osaka. Other chemicals were of the highest purity obtainable. Carp muscle homogenate was prepared by homogenizing carp ordinary muscle with 2 volumes of $0.1 \mathrm{M} \mathrm{NaCl}$ containing $1 \mathrm{~mm}$ EDTA. The centrifugal supernatant of the homogenate at $105,000 \times g$ for 90 minutes was used as sarcoplasmic protein. Carp muscle myofibrils were obtained by the method of TokIwA and MATsUMIYA, ${ }^{11)}$

\section{Measurement of Enzyme Activity}

Cathepsin A activity was measured by hydrolysis of Z-Glu-Phe according to the modified method of MaKINODAN and IKEDA, ${ }^{10)}$ unless otherwise described. The reaction mixture contained $0.6 \mathrm{ml}$ of $0.2 \mathrm{M}$ acetate buffer, $\mathrm{pH} 5.0$, $0.2 \mathrm{~m} l$ of $35 \mathrm{~mm}$ substrate solution and $0.2 \mathrm{ml}$ of enzyme solution was incubated at $37^{\circ} \mathrm{C}$ for 1 hour. The reaction was stopped by the addition of $1 \mathrm{~m} l$ of $5 \%$ trichloroacetic acid and stood for 45

* Dept. Fish., Fac. Agr., Kyoto Univ., Kyoto, Japan. （豊原治彦・牧之段保夫・池田静德： 京都大学農学 部水産学科)。 
minutes at room temperature. A blank was prepared in the same manner except for that the substrate solution was added after adding tichloroacetic acid. The mixture was brought to $5 \mathrm{ml}$ by adding distilled water and filtered through Toyo No $5 \mathrm{c}$ filter paper. One $\mathrm{m} l$ of the filtrate was used for the colorimetric determination according to the method of YEMM and CockING. ${ }^{12}$ ACtivity was expressed as nanomoles of phenylalanine released or the absorbance at $570 \mathrm{~nm}$ per $\mathrm{m} l$ of the enyzme solution per hour.

Activities of cathepsin B, C and D were determined according to the method of BARRETT, ${ }^{13)}$ DE LA HABA et al. ${ }^{14)}$ and MAKINODAN and IKEDA, ${ }^{10)}$ respectively.

\section{Determination of Protein}

Protein was determined by the method of LowRY et $\left.a^{15}{ }^{15}\right)$ or the absorbance at $280 \mathrm{~nm}$.

\section{Electrophoresis}

Disc electrophoresis was carried out according to the method of DAvis. ${ }^{10)}$ After electrophoresis at $4^{\circ} \mathrm{C}$, one of the gels was stained with Coommassie brilliant blue. Another gel was cut in $3 \mathrm{~mm}$ slices and extracted with aliquots of $0.2 \mathrm{M}$ acetate buffer, $\mathrm{pH} 5.0$. Then the activity was measured.

Preparative electrofocusing was performed with the LKB 2117 Multiphor.

The effect of carp muscle cathepsin A on the muscle homogenate was determined with slab SDS polyacrylamide gel electrophoresis by the method of SuzukI. ${ }^{17)}$ One $\mathrm{m} l$ of the reaction mixture containing $1.26 \mathrm{mg}$ of muscle homogenate, $2 \mu \mathrm{g}$ of cathepsin $\mathrm{A}$ and $100 \mathrm{ppm}$ chloramphenicol was incubated with $0.13 \mathrm{M}$ acetate buffer, $\mathrm{pH} 5.0$, or $0.13 \mathrm{~m}$ sodium phosphate buffer, $\mathrm{pH} 6.5$, at $37^{\circ} \mathrm{C}$ for 24 hours. The control contained $1 \mathrm{~mm}$ Dip-F in addition to the reaction mixture to inhibit the enzyme.

\section{Results and Discussion}

\section{Purification of Carp Muscle Cathepsin A}

All procedures were performed at $0-4^{\circ} \mathrm{C}$, unless otherwise described. Cathepsin $\mathrm{A}$ has been reported to be stabilized by both chloride ion and sucrose. ${ }^{18,1 \theta)}$ These stabilizing effects were also recognized about partially purified carp muscle cathepsin A in our preliminary experiment. Therefore, the buffers used for chromatography contained $20 \mathrm{~mm} \mathrm{NaCl}$ and $100 \mathrm{~mm}$ sucrose.

One kilogram of carp ordinary muscle was homogenized with 2 volumes of $0.1 \mathrm{M} \mathrm{NaCl}$ containing $1 \mathrm{~mm}$ EDTA in a Waring blender. After standing for 3 hours, the homogenate was centrifuged at $13,000 \times g$ for 30 minutes. The obtained supernatant was dialyzed overnight against $0.1 \mathrm{M} \mathrm{NaCl}$ containing $1 \mathrm{~mm}$ EDTA to give a crude enzyme solution.

To the crude enzyme solution, $1 \mathrm{~N} \mathrm{HCl}$ was added to make $\mathrm{pH}$ about 4.2 and the suspension was heated at $30-33^{\circ} \mathrm{C}$ for 10 minutes. The precipitate was removed by centrifugation, and then $\mathrm{pH}$ of the supernatant was restored to original $\mathrm{pH}$ with $1 \mathrm{~N} \mathrm{NaOH}$. The precipitate was removed by centrifugation to get an acid treated fraction.

Powered ammonium sulfate was added to the acid treated fraction to $60 \%$ saturation. After standing for 3 hours, the precipitate was collected by centrifugation at $13,000 \times g$ for 30 minutes and dissolved in $0.1 \mathrm{M} \mathrm{NaCl}$ containing $1 \mathrm{~mm}$ EDTA. This solution was dialyzed overnight against $0.1 \mathrm{M}$ $\mathrm{NaCl}$ containing 1 mM EDTA.

Cold acetone of $-20^{\circ} \mathrm{C}$ was added to the ammonium sulfate fraction to give $30 \%$ acetone solution $(\mathrm{v} / \mathrm{v})$. After standing for 2 hours at $-20^{\circ} \mathrm{C}$, the precipitate was removed by centrifugation and cold acetone of $-20^{\circ} \mathrm{C}$ was added to the supernatant to give $60 \%$ acetone solution $(\mathrm{v} / \mathrm{v})$. After standing for 2 hours at $-20^{\circ} \mathrm{C}$, the precipitate was collected by centrifugation and dissolved in $5 \mathrm{~mm}$ Tris- $\mathrm{HCl}$ buffer, $\mathrm{pH} 8.0$, containing $1 \mathrm{~mm}$ EDTA, $20 \mathrm{~mm} \mathrm{NaCl}$ and $100 \mathrm{~mm}$ sucrose (buffer A). This solution was dialyzed against buffer $\mathrm{A}$ to give an acetone fraction.

The acetone fraction was applied to a column $(2.2 \times 18 \mathrm{~cm})$ of DEAE-Sephadex A-50 equilibrated with buffer A. This column was washed with buffer $A$ and eluted stepwise with $0.12 \mathrm{M}$, $0.22 \mathrm{M}$ and $0.52 \mathrm{M} \mathrm{NaCl}$ in buffer $A$. Cathepsin $D$ was eluted with $0.12 \mathrm{M} \mathrm{NaCl}$, while cathepsin $\mathrm{A}$ was eluted with $0.22 \mathrm{M} \mathrm{NaCl}$ in buffer A (Fig. 1). Further purification of carp muscle cathepsin D was described elsewhere. ${ }^{20}$ Cathepsin A fractions were pooled, dialyzed overnight against $1 \%$ glycine and concentrated to $3-4 \mathrm{~m} l$ with Collodion Bag.

The concentrated solution was applied to a preparative electrofocusing. After electrofocusing at 3-8 W for 10 hours, each gel was packed into a small column and eluted with aliquots of $0.2 \mathrm{M}$ acetate buffer, $\mathrm{pH}$ 5.0. The $\mathrm{pH}$ of each fraction was measured by suspending each gel in small amount of distilled water. To remove Ampholine, each fraction was dialyzed overnight against $0.2 \mathrm{M}$ 


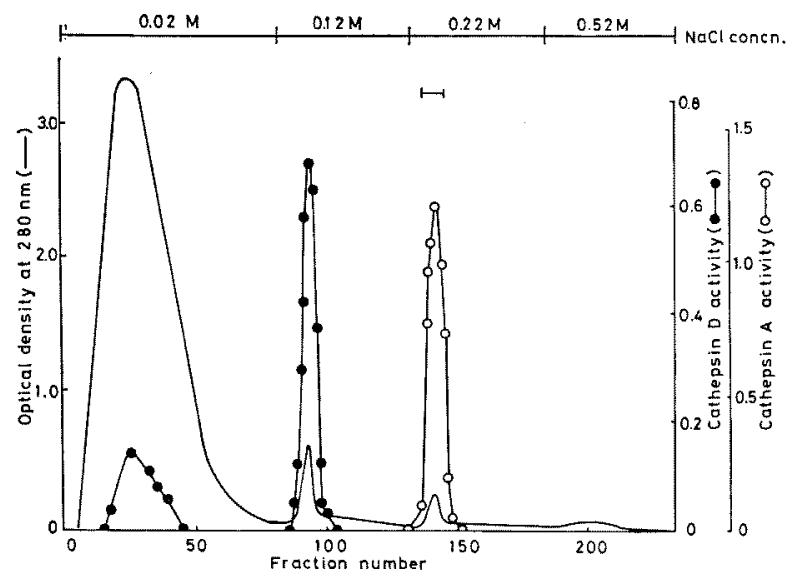

Fig. 1. Chromatography of the acetone fraction on DEAE-Sephadex A-50. Elution was carried out at the flow rate of $40 \mathrm{ml}$ per hour and $5 \mathrm{~m} l$ of each fraction was collected. Cathepsins A and $\mathrm{D}$ activities were represented as $\Delta \mathrm{A}_{570}$ and $\Delta \mathrm{A}_{760}$ per $\mathrm{ml}$ of enzyme solution per hour, respectively.

acetate buffer, pH 5.0. Then the enzyme activity was measured. Cathepsin A activity was detected in the fraction at $\mathrm{pH} 4.6$ (Fig. 2). From this result, the isoelectric point of carp muscle cathep$\sin A$ was estimated to be 4.6. The enzyme fractions were pooled, concentrated with Col-

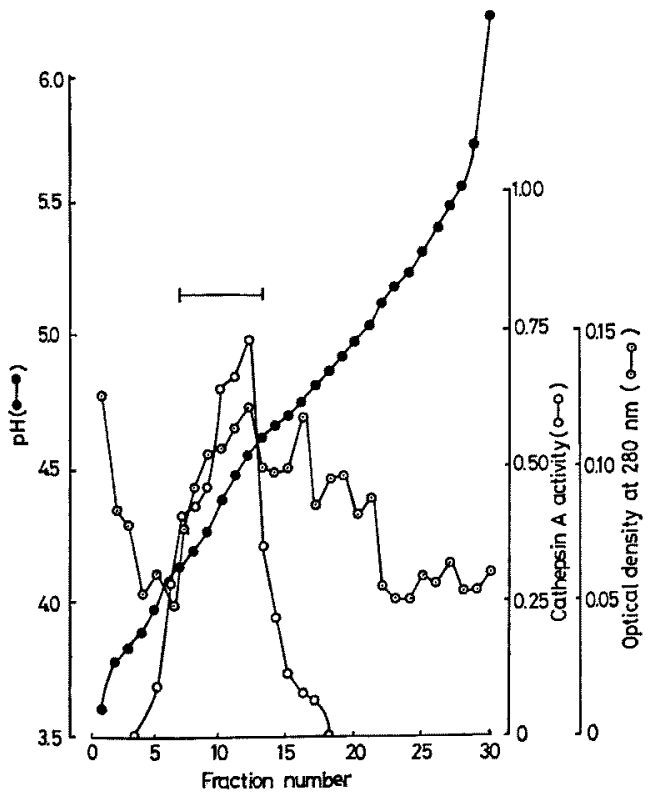

Fig. 2. Chromatography of the DEAE-Sephadex A-50 fraction on a preparative electrofocusing in a $\mathrm{pH}$ gradient from 4.0 to 6.0 . Cathepsin $\mathrm{A}$ activity was represented as $\Delta \mathrm{A}_{\mathrm{b70}}$ per $\mathrm{m} l$ of enzyme solution per hour. lodion Bag and applied to a column $(1.5 \times 90 \mathrm{~cm})$ of Sepharose 6B equilibrated with $50 \mathrm{~mm}$ sodium phosphate buffer, pH 7.0, containing 1 mM EDTA, $20 \mathrm{~mm} \mathrm{NaCl}$ and $100 \mathrm{~mm}$ sucrose. The enzyme was eluted as a single peak corresponding to a protein peak (Fig. 3). The active fractions were pooled and kept at $-20^{\circ} \mathrm{C}$.

Above purification procedures are summarized in Table 1. About 1,700-fold purification was achieved with an overall yield of about $1.5 \%$.

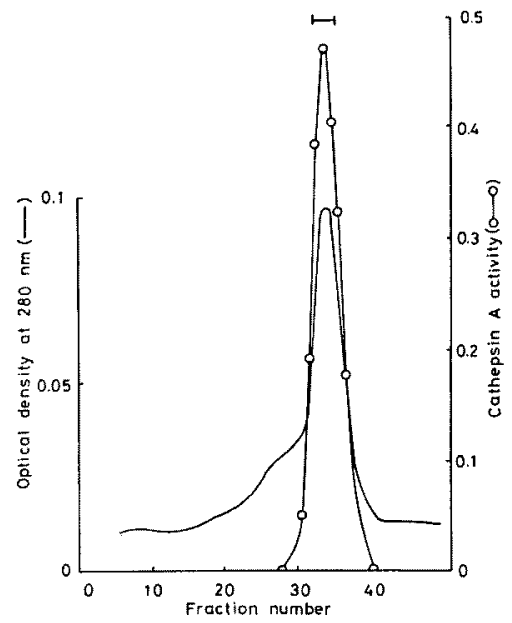

Fig. 3. Chromatography of the electrofocusing fraction on Sepharose 6B. Elution was carried out at the flow rate of $6 \mathrm{~m} /$ per hour and $3 \mathrm{ml}$ of each fraction was collected. Cathepsin A activity was represented as $\Delta \mathrm{A}_{\varepsilon 70}$ per $\mathrm{m} l$ of enzyme solution per hour. 
Table 1. Typical purification chart of carp muscle cathepsin A

\begin{tabular}{lccccc}
\hline \multicolumn{1}{c}{ Fraction } & $\begin{array}{c}\text { Volume } \\
(\mathrm{m} l)\end{array}$ & $\begin{array}{c}\text { Protein } \\
(\mathrm{mg} / \mathrm{m} l)\end{array}$ & Activity*1 & $\begin{array}{c}\text { Purification } \\
(\text {-fold })\end{array}$ & $\begin{array}{c}\text { Yield } \\
(\%)\end{array}$ \\
\hline Crude enzyme & 2720 & 6.54 & 0.279 & 1 & 100 \\
Acid treatment (pH 4.2) & 1570 & 3.80 & 0.394 & 2.5 & 82 \\
$\begin{array}{l}\text { Ammonium sulfate } \\
\text { fractionation (0-60\%) }\end{array}$ & 85 & 10.2 & 3.43 & 8 & 38 \\
$\begin{array}{l}\text { Acetone fractionation (30-60\%) } \\
\begin{array}{l}\text { DEAE-Sephadex A-50 } \\
\text { chromatography }\end{array}\end{array} \quad 50$ & 3.50 & 4.06 & 28 & 27 \\
$\begin{array}{l}\text { Electrofocusing } \\
\text { Sepharose 6B gel filtration }\end{array}$ & 18 & 0.103 & 1.64 & 379 & 8.8 \\
\end{tabular}

*1 Nanomoles phenylalanine equivalents per $\mathrm{ml}$ of enzyme solution per hour.

*2 Calculated from the absorbance at $280 \mathrm{~nm}$.

The purity of the final enzyme preparation was determined by disc electrophoresis. A single protein band coinciding with the enzyme activity was observed (Fig. 4). Neither activity of cathepsins B, C nor D was observed in the purified preparation.

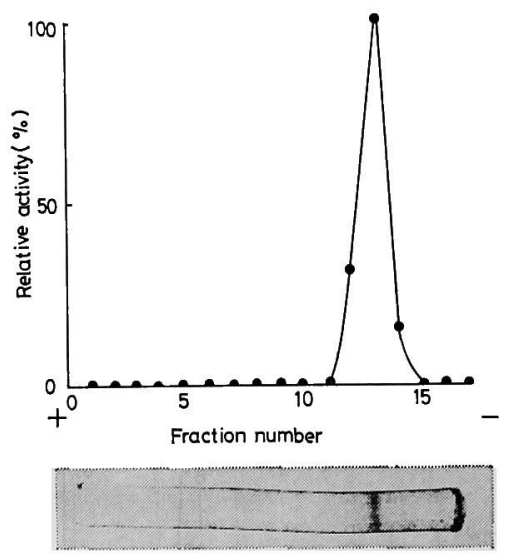

Fig. 4. Disc electrophoresis of the purified enzyme. The sample ( $40 \mu \mathrm{g}$ protein) was loaded on a $7.5 \%$ polyacrylamide gel column.

\section{Properties of the Enzyme}

1) Effect of $\mathrm{pH}$ on activity

As shown in Fig. 5, the enzyme was active between $\mathrm{pH} 3.0$ and 6.0 with optimum $\mathrm{pH}$ at 5.0 for Z-Glu-Phe. However, no activity was detected at $\mathrm{pH} 6.5$ which was near to the post-mortem $\mathrm{pH}$ value. ${ }^{21)}$

MAKINODAN and IKEDA ${ }^{10)}$ and Iwata et al. ${ }^{18)}$ reported that optimum pHs of partially purified carp muscle cathepsin A for Z-Glu-Phe were $\mathrm{pH}$ 5.0 and 4.6, respectively. Our present result coincided with theirs.

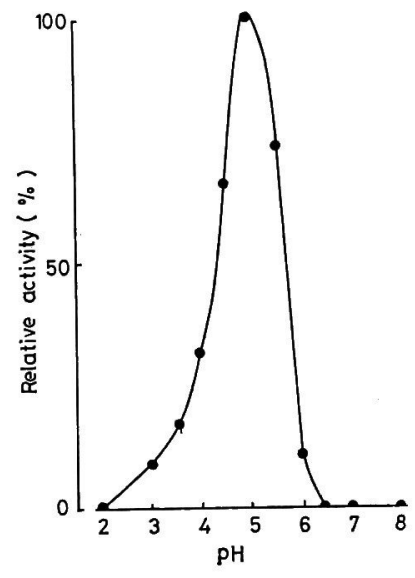

Fig. 5. Effect of $\mathrm{pH}$ on hydrolysis of Z-Glu-Phe. The buffer contained $0.01 \mathrm{M}$ acetic acid and $0.01 \mathrm{M}$ tricine was adjusted to various $\mathrm{pH}$ values with $1 \mathrm{~N} \mathrm{HCl}$ or $1 \mathrm{~N} \mathrm{NaOH}$ according to the method of KAWAMURA et al. ${ }^{\text {) }}$

2) Effect of inhibitors on activity

Table 2 shows the effect of inhibitors on the enzyme activity. Chelating reagents such as EDTA and $o$-phenanthroline had no effect. However, Dip-F, PMSF, iodoacetamide, antipain and $\mathrm{HgCl}_{2}$ completely inhibited the enzyme activity. This result coincided with one of MAKINODAN and IKEDA ${ }^{10)}$. IwATA et al. ${ }^{18)}$ reported that 2-mercaptoethanol inhibited the enzyme activity to $71 \%$, but in our experiment 2 -mercaptoethanol, $\mathrm{NaI}$ and $\mathrm{NaBr}$ activated the enzyme. From these results, serine and cysteine residues may be involved in the active site.

3) Substrate specificity

Z-Glu-Tyr is known to be a typical substrate for cathepsin A from mammalian tissues. However, carp muscle cathepsin A showed more affinity 
Table 2. Effect of inhibitors on the activity of carp muscle cathepsin A

\begin{tabular}{|c|c|c|}
\hline Inhibitor & Concentration & $\begin{array}{c}\text { Relative } \\
\text { activity } \\
(\%)\end{array}$ \\
\hline None & & 100 \\
\hline EDTA & $1 \mathrm{~mm}$ & 100 \\
\hline o-Phenanthroline & $1 \mathrm{~mm}$ & 100 \\
\hline 2-Mercaptoethanol & $1 \mathrm{~mm}$ & 142 \\
\hline Iodoacetic acid & $1 \mathrm{~mm}$ & 88 \\
\hline Iodoacetamide & $1 \mathrm{~mm}$ & 0 \\
\hline$p \mathrm{CMB}$ & $0.1 \mathrm{mM}$ & 63 \\
\hline Dip-F & $0.1 \mathrm{~mm}$ & 0 \\
\hline PMSF & $0.1 \mathrm{mM}$ & 4 \\
\hline TLCK & $0.1 \mathrm{~mm}$ & 66 \\
\hline $\mathrm{HgCl}_{2}$ & $0.1 \mathrm{~mm}$ & 8 \\
\hline $\mathrm{HgCl}_{2}+\mathrm{EDTA}$ & $\begin{array}{l}0.1 \mathrm{~mm} \\
\text { (each) }\end{array}$ & 74 \\
\hline $\mathrm{NaI}$ & $1 \mathrm{~mm}$ & 125 \\
\hline $\mathrm{NaBr}$ & 1. $\mathrm{mM}$ & 123 \\
\hline $\begin{array}{l}\text { Soy bean trypsin } \\
\text { inhibitor }\end{array}$ & $50 \mu \mathrm{g} / \mathrm{m} l$ & 59 \\
\hline Pepstatin & $1 \mu \mathrm{g} / \mathrm{m} l$ & 92 \\
\hline Antipain & $2 \mu \mathrm{g} / \mathrm{m} l$ & 0 \\
\hline Leupeptin & $2 \mu \mathrm{g} / \mathrm{m} l$ & 67 \\
\hline
\end{tabular}

Table 3. Substrate ${ }^{-}$specificity of carp muscle cathep$\sin \mathrm{A}$

\begin{tabular}{lrl}
\hline Substrate & $\begin{array}{c}\text { Relative } \\
\text { activity } \\
(\%)\end{array}$ & Km (mM) \\
\hline Z-Glu-Phe & 100 & 3.52 \\
Z-Glu-Tyr & 61 & 4.76 \\
Z-Phe-Tyr & 81 & N.D* \\
Z-Gly-Phe & 31 & N.D* \\
Z-Gly-Pro & 0 & N.D* \\
\hline Not determined. & &
\end{tabular}

for Z-Glu-Phe than Z-Glu-Tyr (Table 3), as reported by MAKINODAN and IKEDA. ${ }^{10}$ ) The Km values determined by Lineweaver-Burk plot for Z-Glu-Phe and Z-Glu-Tyr were $3.52 \mathrm{~mm}$ and $4.76 \mathrm{~mm}$, respectively. KAWAMURA et $a l^{22)}$ reported that pig kidney cathepsin A hydrolyzed Z-Gly-Pro slightly, but carp muscle cathepsin A did not hydrolyzed Z-Gly-Pro at all.

Bovine spleen cathepsin $\mathrm{A}$ is reported to show certain endopeptidase activity. ${ }^{23,24)}$ Therefore, we examined the activity for commercially obtained protein substrates such as hemoglobin, myoglobin, bovine serum albumin, ovalbumin, chymotrypsinogen $\mathrm{A}$, cytochrome $\mathrm{c}$, insulin and glucagon. We also examined for endogenous substrates such as muscle homogenate, myofbrillar protein and sarcoplasmic protein, but the enzyme did not show any activity against such substrates.

\section{4) Molecular weight}

The molecular weight of carp muscle cathepsin A was determined by gel filtration on Sepharose 6B (Fig. 6). The elution of the enzyme was confirmed by the absorbance at $280 \mathrm{~nm}$ and the enzyme activity. The molecular weight was estimated 36,000. MAKINODAN and IKEDA ${ }^{10)}$ showed 34,000 and IwATA et al. ${ }^{25)}$ showed 81,000 for partially purified preparations. Our result coincided with the former. For the reason of the difference between ours and the latter is unknown.

Cathepsin A purified from bovine spleen, ${ }^{4}$ rat liver $^{(8)}$ and pig kidney ${ }^{7,8)}$ were reported to be high molecular weight oligomers, but carp muscle cathepsin A did not show such a high molecular weight.

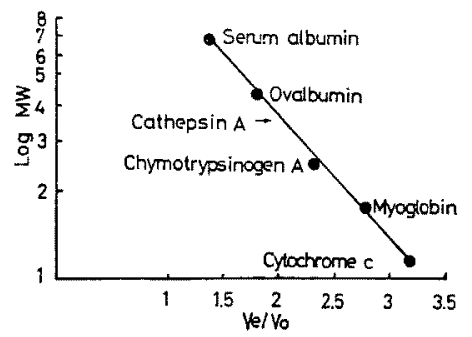

Fig. 6. Molecular weight estimation of carp muscle cathepsin $\mathrm{A}$ by Sepharose $6 \mathrm{~B}$ gel filtration. The marker proteins were; bovine serum albumin, 67,000 ; ovalbumin, 45,000 ; chymotrypsinogen A, 25,000; myoglobin, 18,000; cytochrome c, 12,400 .

\section{Effect of the Enzyme on Autolysis}

Effect of the enzyme on carp muscle homogenate was examined by slab SDS polyacrylamide gel electrophoresis (Fig. 7). The mixture of carp muscle homogenate and the enzyme was incubated at $\mathrm{pH} 5.0$ and 6.5 for 24 hours.

At $\mathrm{pH} 5.0$, the degradation of high molecular weight protein supposed to be myosin heavy chain, 67,000 dalton protein, $50,000-55,000$ dalton protein and 45,000 dalton protein supposed to be actin were recognized (Fig. 7-b). But this degradation was not influenced by Dip-F, the inhibitor of the enzyme (Fig. 7-c). Therefore, the enzyme did not seem to be concerned with the degradation. Cathepsin D degraded myofibrils to some extent at $\mathrm{pH} 5.0,{ }^{20}$ so this degradation was probably by cathepsin D existing in muscle 


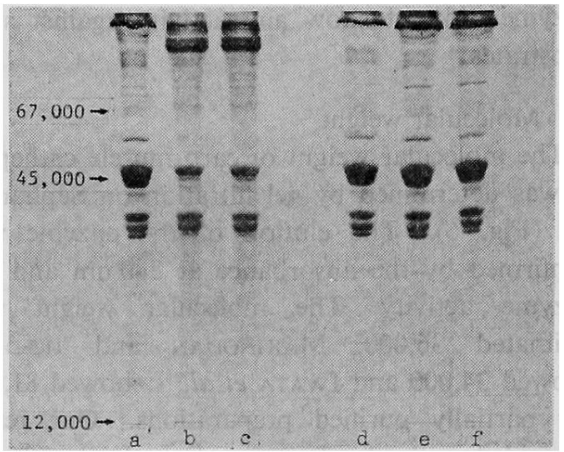

Fig. 7. Slab SDS polyacrylamide gel electrophoresis of carp muscle homogenate treated with purified

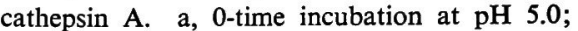
b, without Dip-F at pH 5.0; c, with Dip-F at $\mathrm{pH} 5.0$; d, 0 time-incubation at $\mathrm{pH} 6.5$; e, without Dip-F at pH 6.5; f, with Dip-F at pH 6.5.

homogenate. After death of carp, the muscle $\mathrm{pH}$ decreases about 6.5. ${ }^{21}$ At $\mathrm{pH}$ 6.5, however, autolysis was weak and no other remarkable change was observed than the degradation of myosin heavy chain and the increase of the protein band above 67,000 dalton protein (Fig. 7-e). Cathepsin A was not concerned with it at $\mathrm{pH} 6.5$ as well as at $\mathrm{pH}$ 5.0.

Previously MAKINODAN and IKEDA ${ }^{10)}$ reported that cathepsin $\mathrm{A}$ acted on sarcoplasmic protein, but in this study the enzyme did not degrade myofibrillar and sacoplasmic protein. The difference of the results was probably due to the fact that the autolysis of sarcoplasmic protein was not completely eliminated in the previous paper. The action of the enzyme on myofibrillar and sarcoplasmic proteins will be described in detail in the next paper.

We examined the subcellular distribution of the enzyme, but clear data were not obtained. Judging from the properties, however, carp muscle cathepsin A belongs to lysosomal carboxypeptidases A defined by Barrett. ${ }^{26)}$ Cathepsin A and $\mathbf{D}$ were known to act on hemoglobin synergistically. ${ }^{10,27)}$ The synergistic activity of both enzymes on various proteins is now being pursued.

\section{References}

1) J.S. Fruton and M. Bergmann: J. Biol. Chem., 130, 19-27 (1939).

2) J. K. MCDonald and C. Schwabe: in "Proteinases in mammalian cells and tissues" (ed. by
A. J. BARReTt), North-Holland publishing Co., Amsterdam, 1977, pp. 329-335.

3) A. A. IODICE: Arch. Biochem. Biophys., 121, 241-242 (1967).

4) A. I. Logunov and V. N. Orekhovich: Biokhimiya, 37, 855-861 (1972).

5) S. L. TAYlor and A. L. TAPPEL: Biochem. Biophys. Acta, 341, 99-111 (1971).

6) K. Matsuda and E. Misaka: J. Biochem., 76, 639-649 (1974).

7) Y. Kawamura, T. Matoba, T. Hata, and E. DoI: J. Biochem., 76, 915-924 (1974).

8) Y. Kawamura, T. Matoba, T. Hata, and E. Dor: J. Biochem., 77, 729-737 (1975).

9) Y. MAKINODAN and S. IKedA: Bull. Japan. Soc. Sci. Fish., 37, 1002-1106 (1971).

10) Y. MAKINODAN and S. IKedA: Bull. Japan. Soc. Sci. Fish., 42, 239-247 (1976).

11) T. Tokiwa and H. MatsumiYa: Bull. Japan. Soc. Sci. Fish., 35, 1099-1109 (1969).

12) Е. M. Yемм and E. C. Cocking: Analyst, 80, 209-213 (1955).

13) A. J. Barretr: in "Proteinases in mammalian cells and tissues" (ed. by A. J. BarretT), NorthHolland Publishing Co., Amsterdam, 1977, pp. 210-205.

14) G. de La Haba, P. S. Cammarata, and S. N. TimashefF: J. Biol. Chem., 234, 316-319 (1959).

15) O. H. Lowry, N. J. Rosebrough, A. L. FarR, and R. J. Randall: J. Biol. Chem., 193, 265275 (1951).

16) B. J. Davis: Ann. N.Y. Acad. Sci., 121, 404-427 (1964).

17) K. SuzuKi: Genetics, 31, 43-49 (1977).

18) K. Iwata, N. Nakal, K. Kobashi, and J. Hase: Bull. Japan. Soc. Sci. Fish., 43, 307-314 (1977).

19) E. Dor: J. Biochem., 75, 881-887 (1974).

20) Y. Makinodan, T. AKasaka, H. Toyohara, and S. IKEDA: J. Food Sci. 47, 647-652 (1982).

21) Y. Makinodan, M. Hirotsuka, and S. Ikeda: Bull. Japan. Soc. Sci. Fish., 46, 1507-1510 (1980).

22) Y. Kawamura, T. Matoba, T. Hata, and E. DoI: J. Biochem., 81, 435-441 (1976).

23) N. Lichtenstein and J. S. Fruton: Proc. Natl. Acad. Sci. U.S., 46, 781-791 (1960).

24) A. I. Logunov and V. N. OReKhovich: Biochem. Biophys. Res. Commun., 46, 1161-1168 (1972).

25) K. Iwata, K. Kobashi, and J. Hase: Bull. Japan. Soc. Sci. Fish., 43, 181-193 (1977).

26) A. J. BARRETT: in "Proteinases in mammalian cells and tissues" (ed. by A. J. Barretr), NorthHolland publishing Co., Amsterdam, 1977, pp. 36.

27) A. A. Iodice, V. Leong, and I. M. Weinstock: Arch. Biochem. Biophys., 117, 477-486 (1966). 